\title{
Biosimilar uptake by British local formularies: a cross sectional study
}

\author{
Saja Alnahar ${ }^{1}$ (D) Rachel A. Elliott ${ }^{2} \cdot$ Murray D. Smith ${ }^{3}$
}

Received: 12 November 2016/Accepted: 4 August 2017/Published online: 4 September 2017

(c) The Author(s) 2017. This article is an open access publication

\begin{abstract}
Background Biological medicines are starting to lose their patent protection, so similar, inexact copies (biosimilars) are being developed and licensed. The high acquisition costs of biologics for healthcare providers could be reduced by switching to biosimilars, thus alleviating budgetary pressures and increasing patient access. Therefore, the acceptance of biosimilars by prescribers in Great Britain (GB; England, Scotland, Wales) needs to be described and understood. Objective To determine uptake of the first wave of biosimilars (somatropin, epoetin, filgrastim) by local formularies (lists of preferred medicines for prescribing in local healthcare settings). Settings This study targeted local formularies in GB. Method In November 2014, local formularies (medicines formularies of Acute Trusts and Health Boards in GB) were screened for their approach to listing of biologics and their biosimilars as well as recommendations on usage of these pharmaceuticals. Main Outcomes Measures Listing frequencies of biosimilars. Results One hundred and forty-six British local formularies were screened. Amongst the $80 \%$ of formularies in which brand names were specified, biosimilar filgrastim was the most frequently listed when
\end{abstract}

Saja Alnahar

Saja.alnahar@nottingham.ac.uk

1 Division of Pharmacy Practice and Policy, School of Pharmacy, University of Nottingham, East Drive, University Park, Nottingham NG7 2RD, UK

2 Manchester Centre for Health Economics, Division of Population Health, Health Services Research and Primary Care, School of Health Sciences, Faculty of Biology, Medicine and Health, The University of Manchester, Oxford Road, Manchester M13 9PL, UK

3 Community and Health Research Unit, School of Health and Social Care, University of Lincoln, Lincoln, UK compared to the other targeted biosimilars. Biosimilars were listed in preference to reference biologic medicine in $49 \%$ of local formularies for filgrastim, $11 \%$ for somatropin and in only $6 \%$ for epoetin. Conclusion Although the market for biosimilars can act in parallel to the generic market, their uptake measured using local British formularies was less than what is expected given that the British market for medicines has a strong focus on generics. Finally, geographical variability within GB requires further investigation.

Keywords Biosimilars · Biological medicines · Great Britain · Local formularies

\section{Impacts on practice}

- As the use of brand names in prescribing and reporting adverse drug reactions is part of active monitoring of biological medicines safety, including the biosimilar medicines, local formularies must actively list these medicines using the brand name;

- Specifying preferred brand for prescribing facilitates and promotes local formularies in guiding cost effective and rational medicines utilisation.

\section{Introduction}

Biological medicines (BMPs) provide an innovative method for treating chronic and life-threatening diseases such as cancers, rheumatoid arthritis and multiple sclerosis. Their rapid adoption into clinical practice has resulted in a substantial share of the pharmaceutical market; for 
example, in 2012-2013, 27\% of total pharmaceutical sales in Europe were BMPs [1]. Moreover, eight of the top ten bestselling pharmaceuticals in 2013 in Europe were BMPs. It is expected that BMPs will maintain the same market share into 2016 [2, 3] and likely beyond. BMPs have significantly improved health and disease outcomes, but their widespread utilisation is financially challenging to healthcare providers worldwide [4].

In 2013-2014, in England, seven out of the top ten most prescribed medicines in terms of cost to the National Health Service (NHS) were BMPs [5]. Notable though is that all seven will lose their patent protection by 2018 [6]. Patent expiry creates an opportunity for developing and licensing similar copies of off-patent BMPs-called biosimilar medicines (BSPs) [7]. Unlike conventional generic medicines, BSPs are not identical but similar copies of their reference BMP (R-BMP). The inability to produce identical copies is related to the complex and heterogenic molecular structure of these medicines, and being produced by not fully controllable living systems $[4,8]$.

In their analysis of the European BSP market, Rovira et al. reported that BSPs offer price reductions of between 10 and $35 \%$ [9]. Although this is a modest price reduction in comparison to conventional generic medicines, the overall cost saving to health service providers is expected to be significant due to the high unit costs and extensive use of BMPs [9]. The European Generic Medicines Association reported that the European Union might save upwards of $€ 1.6$ billion/year for the scenario in which a $20 \%$ price reduction occurs on five off-patent BMPs [10]. Furthermore, it has been suggested that the availability of BSPs might alter medical practice and increase compliance to clinical guidelines [11, 12].

In Europe, BSPs can be launched after being centrally assessed and licensed by the European Medicines Agency (EMA) for safety, quality and efficacy $[8,11]$. While the EMA mandates full quality submission in order to license a BSP, it does permit evidence based extrapolation of the clinical outcomes from one tested indication to closely related others $[13,14]$.

In Great Britain (GB), the Medicines and Healthcare products Regulatory Agency (MHRA) directs prescribers to use brand name in prescribing any BMP and its BSPs [15]. Brand name-based prescribing and reporting facilitates capture of safety issues related to BMPs including BSPs [15].

Despite being a generically-driven market [16], the uptake of BSPs in Britain seems to have been relatively limited when compared to other European countries [14]. According to the British Generic Manufacturers Association factors related to physicians' lack of confidence in prescribing BSPs, absence of encouraging national policies and banned substitution at pharmacy level have resulted in slow adoption of BSPs [14]. Lack of confidence might relate to physicians questioning the safety and efficacy of BSPs [11]. This might be at least partly explained by the abridged approach the EMA follows in assessing clinical efficacy of BSPs [13]. One exception is granulocyte-colony stimulating factor (G-CSF)-filgrastim BSP, which is achieving an uptake rate similar to that of conventional generic medicinal products [2].

One approach to evaluating prescribers' acceptance of BSPs is through assessing uptake of BSPs in local medicines formularies. The National Institute for Health and Care Excellence (NICE) defines local formularies as "the output processes to support the managed introduction, utilisation or withdrawal of healthcare treatments within a health economy, service or organisation" [17]. Local formularies are working documents that are subject to regular review and change. They tend to be robust on treatments used frequently and weak on occasionally used ones (that need to be available for a complete and comprehensive service). Local formularies can act as prescribing guiding tool at local settings [18]. Heal et al. (2004) reported that more than $80 \%$ of their study participants were guided by local formularies [19]. Accordingly, assessing BSP listing in local formularies might reflect acceptance of these products by prescribers.

\section{Aim of the study}

To determine uptake acceptance of first wave BSPs licensed and marketed in GB prior to 2015 [somatropin $(\mathrm{HGH})$, epoetin (EPO) and filgrastim (G-CSF)] by local formularies.

\section{Ethics approval}

Ethical approval was not needed as local formularies throughout the UK are publically available documents included in the freedom of information scheme.

\section{Method}

During November-December 2014, a list of 157 Acute Trusts (accountable organisations within NHS England that manage and control the performance, services quality and financial efficiency of clusters of hospitals in England) was acquired from the NHS England website two Acute Trusts were excluded as one was dissolved and the other one was still in process of developing a formulary list. Details of the 14 Regional Health Boards in Scotland and 7 Local Health 
Table 1 - Formulary assessment criteria

\begin{tabular}{|c|c|c|}
\hline No. & Assessment criterion & Definition \\
\hline 1. & $\begin{array}{l}\text { Is this formulary a joint } \\
\text { formulary? (yes/no) }\end{array}$ & $\begin{array}{l}\text { Formulary list that is developed and/or used by more than one healthcare setting (primary and/or } \\
\text { secondary care) }\end{array}$ \\
\hline 2. & $\begin{array}{l}\text { Is the targeted medicine listed? } \\
\text { (yes/no) }\end{array}$ & $\begin{array}{l}\text { BNF chapter } 6.5 .1^{*} \text { : somatropin }(\mathrm{HGH}) \\
\text { BNF chapter } 9.1 .3^{* *} \text { : epoetin alfa }(\mathrm{EPO}) \\
\text { BNF chapter } 9.1 .6^{* * *} \text { : filgrastim }(\mathrm{G}-\mathrm{CSF})\end{array}$ \\
\hline 3. & $\begin{array}{l}\text { How it is listed? (formulary/non- } \\
\text { formulary) }\end{array}$ & $\begin{array}{l}\text { Formulary Medicinal product that is routinely available for prescription } \\
\text { Non- } \\
\text { formulary } \\
\text { Medicinal product that is not routinely available for prescription. However, if it is } \\
\text { deemed needed, it will be made available for the patient }\end{array}$ \\
\hline 4. & $\begin{array}{l}\text { What is the listing approach? } \\
\text { (brand name/INN/both) }\end{array}$ & As per brands listed in BNF chapters 6.5.1, 9.1.3 and 9.1.6 \\
\hline 5. & $\begin{array}{l}\text { What are the listed brands? } \\
\text { (R-BMP/BSP/both) }\end{array}$ & $\begin{array}{l}\text { BNF chapter 6.5.1: } 1 \mathrm{R}-\mathrm{BMP} \text { and } 1 \mathrm{BSP} \\
\text { BNF chapter 9.1.3: } 1 \mathrm{R}-\mathrm{BMP} \text { and } 2 \text { BSPs } \\
\text { BNF chapter 9.1.6: } 1 \text { R-BMP and } 3 \text { BSPs }\end{array}$ \\
\hline 6. & $\begin{array}{l}\text { What is the preferred type? } \\
\text { (R-BMP/BSP/not specified) }\end{array}$ & $\begin{array}{l}\text { Being the only listed brand/type; } \\
\text { Clearly stated that this brand/type is the preferred for prescription; or } \\
\text { Brand/type listed as formulary while other brands/type listed as non-formulary. }\end{array}$ \\
\hline 7. & $\begin{array}{l}\text { Are there clear restrictions in } \\
\text { prescribing? (yes/no) }\end{array}$ & $\begin{array}{l}\text { Whether or not there are specified restrictions in terms of who can prescribe these products and/or } \\
\text { prescribing settings i.e. primary or secondary care }\end{array}$ \\
\hline 8. & $\begin{array}{l}\text { Is there specified brand of choice? } \\
\text { (yes/no) }\end{array}$ & If it is clearly stated that a specific brand is considered as the brand of choice \\
\hline 9. & $\begin{array}{l}\text { Are there special population } \\
\text { considerations? (yes/no) }\end{array}$ & $\begin{array}{l}\text { If there are considerations related to patients' age, medical history and/or life style factors that might } \\
\text { affect type/brand of preference (R-BMP or BSP) }\end{array}$ \\
\hline 10. & $\begin{array}{l}\text { Are there special indications' } \\
\text { considerations? (yes/no) }\end{array}$ & $\begin{array}{l}\text { If there are considerations related to indications that might affect type/brand of preference (R-BMP or } \\
\text { BSP) }\end{array}$ \\
\hline
\end{tabular}

$B N F$ British National Formulary 68th Edition; BMP biological medicinal product; BSP biosimilar medicinal product; INN international nonproprietary name (molecular name); $R$ - $B M P$ reference biological medicinal product

* 6.5.1: drugs used in hypothalamic and anterior pituitary hormones and anti-oestrogen; 1 R-BMP and 1 BSP brand

** 9.1.3: drugs used in hypoplastic, haemolytic, and renal anaemias; 1 R-BMP and 2 BSP brands

*** 9.1.6: drugs used in neutropenia; 1 R-BMP and 3 BSP brands

Boards in Wales (accountable organisations within NHS Scotland and NHS Wales that are responsible for the delivery of healthcare services to the local population) were acquired from Scottish Government and NHS Wales websites. Northern Ireland was excluded as there was an initiative underway to develop a joint formulary for the whole country, and some of its chapters were still under development.

The most recent versions of local medicines formularies were downloaded and examined for their listing of targeted R-BMPs and BSPs according to the criteria given in Table 1. These criteria enabled assessment of: (1) uptake of BSPs, (2) compliance to the MHRA recommendation on brand name prescribing of BMPs, and (3) the consideration given to population or indication-specific recommendations.

The assessment process started by examining whether the listing approach of R-BMP and BSPs was based on using brand name, molecular name or both, as per the British National Formulary (BNF) 68th edition. Then the availability of prescribing guidance in terms of speciality of the prescriber and/or the clinical settings was recorded. Finally, formulary entries were classified and compared according to preferred brand for prescribing. Formulary uptake of targeted BMPs and BSPs was analysed using descriptive statistics in an Excel ${ }^{\circledR} 2010$ spreadsheet.

\section{Results}

One hundred and forty-six formularies were identified: 129 in England, 10 in Scotland and 7 in Wales. Forty-three percent (63/146) of these were joint formularies (the term given to a local formulary developed and/or used simultaneously by more than one healthcare providing organisation).

Formulary uptake and listing approaches varied across the three targeted groups. HGH was listed in 126 formularies achieving the highest percentage of medicine listing, 
Table 2 - Results Summary

\begin{tabular}{|c|c|c|c|}
\hline \multirow[t]{2}{*}{ Investigated attributes } & \multicolumn{3}{|c|}{ Medicine group } \\
\hline & $\begin{array}{l}\text { Filgrastim } \\
\text { (G-CSF) }\end{array}$ & $\begin{array}{l}\text { Epoetin alfa } \\
\text { (EPO) }\end{array}$ & $\begin{array}{l}\text { Somatropin } \\
\text { (HGH) }\end{array}$ \\
\hline \multicolumn{4}{|l|}{ Medicine being listed } \\
\hline Not listed & $27(18 \%)$ & $31(21 \%)$ & $20(14 \%)$ \\
\hline Listed as formulary & $115(79 \%)$ & $107(73 \%)$ & $120(82 \%)$ \\
\hline Listed as non-formulary & $4(3 \%)$ & $8(6 \%)$ & $6(4 \%)$ \\
\hline Total & 146 & 146 & 146 \\
\hline \multicolumn{4}{|c|}{ Clear prescription restrictions } \\
\hline Yes & $78(66 \%)$ & $77(67 \%)$ & $84(67 \%)$ \\
\hline No & $41(34 \%)$ & $38(33 \%)$ & $42(33 \%)$ \\
\hline Total & 119 & 115 & 126 \\
\hline \multicolumn{4}{|l|}{ Listing approach } \\
\hline INN name & $58(49 \%)$ & $44(38 \%)$ & $64(51 \%)$ \\
\hline Brand names & $49(41 \%)$ & $60(52 \%)$ & $59(47 \%)$ \\
\hline Mixed listing & $12(10 \%)$ & $11(10 \%)$ & $3(2 \%)$ \\
\hline Total & 119 & 115 & 126 \\
\hline \multicolumn{4}{|l|}{ Listed brands } \\
\hline Both & $36(59 \%)$ & $21(30 \%)$ & $25(40 \%)$ \\
\hline R-BMP only & $11(18 \%)$ & $48(68 \%)$ & $4(7 \%)$ \\
\hline BSPs only & $14(23 \%)$ & $2(3 \%)$ & $33(53 \%)$ \\
\hline Total & 61 & 71 & 62 \\
\hline \multicolumn{4}{|l|}{ Preferred type } \\
\hline R-BMP & $10(16 \%)$ & $52(73 \%)$ & $29(47 \%)$ \\
\hline BSPs & $30(49 \%)$ & $4(6 \%)$ & $7(11 \%)$ \\
\hline Unclear & $21(34 \%)$ & $15(21 \%)$ & $26(42 \%)$ \\
\hline Total & 61 & 71 & 62 \\
\hline \multicolumn{4}{|l|}{ Specified brand of choice } \\
\hline Yes & $13(21 \%)$ & $4(6 \%)$ & $9(15 \%)$ \\
\hline No & $48(79 \%)$ & $67(94 \%)$ & $53(85 \%)$ \\
\hline Total & 61 & 71 & 62 \\
\hline \multicolumn{4}{|c|}{ Special population considerations ${ }^{\mathrm{a}}$} \\
\hline Yes & $3(5 \%)$ & $8(11 \%)$ & $10(16 \%)$ \\
\hline No & $58(95 \%)$ & $63(89 \%)$ & $52(84 \%)$ \\
\hline Total & 61 & 71 & 62 \\
\hline \multicolumn{4}{|c|}{ Special indication considerations } \\
\hline Yes & $9(15 \%)$ & $7(10 \%)$ & $0(0 \%)$ \\
\hline No & $52(85 \%)$ & $64(90 \%)$ & $62(100 \%)$ \\
\hline Total & 61 & 71 & 62 \\
\hline
\end{tabular}

$B S P$ biosimilar medicinal product; $I N N$ international non-proprietary name (molecular name); $R-B M P$ reference biological medicinal product

${ }^{\mathrm{a}}$ Factors related to patient population or indication that might affect prescriber brand/product of choice

EPO achieved the highest brand name based listing with 60 formularies using brand names. Despite BSP G-CSF being the last of the three groups to be authorised by the EMA, it was most commonly listed in preference to the R-BMP. Table 2 provides more details.
Variations between the countries of GB were seen, with $27 \%$ of English formularies listing BSP G-CSF in preference to the R-BMP, versus $12.5 \%$ and $14.3 \%$ amongst Scottish and Welsh formularies, respectively. In the cases of $\mathrm{HGH}$ and $\mathrm{EPO}, 7 \%$ and $4 \%$ of English formularies preferred BSP over R-BMP; respectively, but no Scottish or Welsh formularies did so.

Only six formularies listed at least one BSP from all three targeted groups. There were no instances of BSPs being preferred to R-BMPs across all three targeted groups, but at the opposite extreme there were only two formularies in which R-BMPs were always preferred over BSPs.

\section{Discussion}

In this study, formulary uptake of BSPs in three different groups was employed as an indicator of clinical acceptance of BSPs in GB. The uptake of BSPs by British local formularies was less than what might be predicted from a classical generically driven market for medicines, and there appeared to be geographic variability in uptake which requires further investigation.

Most frequently listed was HGH, the first licensed BSP [20], however the maximum preference for BSPs over R-BMP was achieved by G-CSF BSPs. On the other hand, brand name-based listing was more frequent in the case of EPO. Despite it not being possible to gain a complete understanding of the variations between targeted groups, it might be explained in large part by the molecular nature, therapy duration and/or patients' demographics, preferences and life style.

Having several other medicinal products within the same group where each has different dosing frequencies, administration devices and storage conditions might affect acceptance of BSPs. For example, one HGH product is a needleless device making it more attractive to paediatric and needle-phobic patients. Another HGH product can be stored out of the refrigerator [21] which might make it the brand of choice for frequent travellers.

G-CSF's molecular structure and short duration of therapy might increase the acceptance of its BSPs. It is a small, easily characterised non-glycosylated molecule that is indicated for short therapeutic periods [22, 23]. However, special population considerations in terms of patient age and therapeutic indications were flagged in those instances when the R-BMP was listed in preference to BSPs. Specifically, the R-BMP was listed as the preferred product for paediatric patients and for stem cell mobilisation. Reluctance to use BSPs in these settings may be because of the lack of clinical trial evidence of their efficacy and/or safety. 
EPO achieved the highest percentage of brand namebased listing. This is most likely due to EPO being a glycosylated protein, in which case each brand has a different glycosylation pattern and hence a different immunogenic profile [24]. In addition, previously reported cases of the life threatening pure red cell aplasia might encourage the use of brand name based listing for EPO whether for the R-BMP or the BSPs [24].

The MHRA has considered several measures in the monitoring of BMPs, including BSPs, such as: demanding brand name-based prescription, and requiring specification of a product's identifiers (brand name, batch number and manufacturer) in reporting adverse drug reactions. Furthermore, prescribers are directed to inform patients and/or carers about a product's brand name and batch number [15]. However, more than one third of local formularies did not specify brand names when listing BMPs in the groups examined in this study. Unintentional switching between brands might affect patients' safety, if not carefully monitored and managed. Such harm might be avoided in the cases of G-CSF and EPO because of their short duration prescription, but possibly not otherwise for HGH which is typically used for prolonged periods.

The limited clinical evidence of BSPs' efficacy has been highlighted as a factor hindering BSPs' acceptance in clinical practice [22]. However, the BSP G-CSF brand that was approved based on results of a pharmacokinetics/ pharmacodynamics trial in healthy volunteers instead of patients, and in a non-comparative safety-focussed study in patients [25] was recommended for use ahead of R-BMP G-CSF in more local formularies than was any other biosimilar/reference pairing.

As there is a proposal to assign different international non-proprietary name (INN) for BSPs, BSPs' manufacturers argue that a differing INN might limit the uptake of BSPs by giving suggestion to the view that BSPs are completely different instead of being a highly similar molecule [26]. The effect of different INN was noted in the case of epoetin zeta and epoetin alfa, where despite both being EPO BSP the latter was more often listed than the former. Moreover, $50 \%$ of formularies that preferred BSP EPO over the R-BMP have not listed epoetin zeta, while the remaining $50 \%$ listed it without brand specification. Of the 27 formularies that did list EPO using its molecular name none included epoetin zeta.

Variations in listing BSPs were observed between England, Scotland and Wales. Although both the Scottish Medicines Consortium and the All Wales Medicines Strategy Group have been actively involved in evaluating BSPs [27, 28], Scottish and Welsh formularies were less likely to list BSPs in preference to the R-BMP compared with their English counterparts.
Research data and analysis indicate that some formularies encourage BSP prescribing. However, variations and lack of specificity in some formularies may suggest a vague understanding of the concept and nature of BMPs in general, and BSPs in particular, by the professionals involved in developing local formularies.

The principal limitation of this study is that the uptake of BSPs has been estimated using local medicines formularies as a proxy for actual prescribing practice. This may not necessarily provide a highly accurate reflection of BSP prescribing, as it is not known to what degree these lists are adhered to.

If equally safe and effective as the originator BMP, lower prices for BSPs could potentially increase access to treatment for more patients, or reduce drug spending in an increasingly constrained financial environment. Engagement is required with prescribers, formulary managers and commissioners to understand the basis for formulary decision-making, identify reasons for variation in prescribing behaviour and develop strategies for more uniform uptake of BSPs. Educational interventions are also needed around adherence to standards of pharmacovigilance to assure drug monitoring and patient safety.

\section{Conclusion}

The results of this study suggest that the uptake of BSPs in Britain is highly variable, and generally less than what is expected, given historically that its market for pharmaceuticals is very much generically driven. Further work is needed to understand why there is such low and variable uptake.

Funding This study is part of a Ph.D. project funded by Yarmouk University-Jordan.

Conflicts of interest The authors declare no potential conflicts of interest.

Open Access This article is distributed under the terms of the Creative Commons Attribution 4.0 International License (http://crea tivecommons.org/licenses/by/4.0/), which permits unrestricted use, distribution, and reproduction in any medium, provided you give appropriate credit to the original author(s) and the source, provide a link to the Creative Commons license, and indicate if changes were made.

\section{References}

1. Committee for Medicinal Products for Human Use. Guideline on similar biological medicinal products containing biotechnologyderived proteins as active substance: non-clinical and clinical issues. London: European Medicines Agency; 2006. 
2. IMS Institute for Healthcare Informatics. Assessing biosimilar uptake and competition in European markets Parsippany: (IMS)Institute for Healthcare Informatics. 2014. https://www. imshealth.com/files/web/IMSH\%20Institute/Healthcare\%20Briefs/ Assessing_biosimilar_uptake_and_competition_in_European_mar kets.pdf. Accessed 30 Aug 2007.

3. Mckinsey and Company. Generating value in generics: finding the next five years of growth. Insights into Pharmaceuticals and Medical Product. Mckinsey and Company. 2013. http://www. pharmatalents.es/assets/files/generating_value.pdf. Accessed 30 Aug 2017.

4. Declerck PJ, Simoens S. European perspective on the market accessibility of biosimilars. Biosimilars. 2012;2:33-40.

5. Health and Social Care Information Centre (HSCIC). Hospital prescribing England 2013-14. London: HSCIC. 2014. http://con tent.digital.nhs.uk/catalogue/PUB15883/hosp-pres-eng-201314rep.pdf. Accessed 30 Aug 2017.

6. GaBI Online. US $\$ 67$ billion worth of biosimilar patents expiring before 2020; 2014. http://www.gabionline.net/Biosimilars/Gen eral/US-67-billion-worth-of-biosimilar-patents-expiring-before2020. Accessed 30 Aug 2017.

7. European Medicines Agency (EMA). Authorisation of medicines. London: EMA. http://www.ema.europa.eu/ema/index.jsp?curl= pages/about_us/general/general_content_000109.jsp\&mid=WC0 b01ac0580028a47. Accessed 30 Aug 2017.

8. Brussels MR. Difficulties with biosimilar drugs. Eur J Cancer. 2005;41(15):2203.

9. Rovira J, Espín J, García L, Olry de Labry A. The impact of biosimilars' entry in the EU market. Andal Sch Public Health. 2011;30:1-83.

10. European Generic Medicines Association (EGA). EGA handbook on biosimilar medicines. European Generic Medicines Association, Brussels: EGA 2010. http://www.bogin.nl/files/ega_biosmi larshandbook.pdf. Accessed 30 Aug 2017.

11. Aapro MS. What does a prescriber think of biosimilars? Oncologie. 2011;13(5):234.

12. Gascón P, Tesch H, Verpoort K, Rosati MS, Salesi N, Agrawal S et al. Clinical experience with Zarzio ${ }^{\circledR}$ in Europe: what have we learned? Support Care Cancer. 2013;21(10):2925-32.

13. European Medicines Agency (EMA). Biosimilars medicines, London: EMA 2013. http://www.ema.europa.eu/ema/index. jsp?curl=pages/medicines/general/general_content_001832.jsp\& mid=WC0b01ac0580bb8fda. Accessed 30 Aug 2017.

14. British Generic Manufacturers Association (BGMA). Biosimilar medicines-maximising benefits for patients and the NHS. London: BGMA. 2013. http://www.britishgenerics.co.uk/admin/files// 1403704797_BGMA-Biosimilars-Briefing-Paper.pdf. Accessed 9 April 2017.

15. Medicines and Healthcare products Regulatory Agency (MHRA). Reporting suspected adverse drug reactions to vaccines and biological medicines, London: MHRA. https://www.gov.uk/drugsafety-update/reporting-suspected-adverse-drug-reactions-to-vac cines-and-biological-medicines. Accessed 30 Aug 2017.
16. Health and Social Care Information Centre (HSCIC). Prescribing and Primary Care Services. Prescriptions Dispensed in the Community. London: HSCIC; 2013. http://content.digital.nhs.uk/ catalogue/PUB11291/pres-disp-com-eng-2002-12-rep.pdf. Accessed 30 Aug 2017.

17. The National Institute for Health and Care Excellence. Developing and updating local formularies. The National Institute for Health and Care Excellence (NICE): London; 2015.

18. Duerden M, Walley T. Prescribing at the interface between primary and secondary care in the UK. Pharmacoeconomics. 1999; 15(5):435-43.

19. Heal SJ, Challinor N, Roome C, Gammie S, Thorne J, Wilcock M. What do GPs think about joint formularies? Pharm J. 2006;276:171-4.

20. Committee for Proprietary Medicinal Products (CPMP). Opinion following an article 7(5) referal for Genotropin International Non-Proprietary Name (INN): somatropin: background information [Internet]. London: EMA; 2003. http://www.ema.europa.eu/ docs/en_GB/document_library/Referrals_document/Genotropin_ 7_5/WC500013685.pd.

21. London New Drugs Group. Comparison of growth hormone products and devices. London: UK Medicines Information (UKmi); 2013. http://www.medicinesresources.nhs.uk/upload/ documents/Evidence/Comparison\%20of\%20growth\%20horm. Accessed 30 Aug 2016.

22. Müller R, Renner C, Gabay C, Cassata G, Lohri A, Hasler P. The advent of biosimilars: challenges and risks. Swiss Med Wkly. 2014;1(144):w13980.

23. Rickwood S, Di Biase S. Searching for terra firma in the biosimilars and non-original biologics market-Insight for the comming decade of change. White Paper-IMS Health Biosimilars and Non-Original Biologics. IMS Health. 2013.

24. Schellekens H. Biosimilar therapeutics-what do we need to consider? NDT Plus. 2009;2(suppl 1):i27-36.

25. Jimenez AG, Brake B. Biosimilars in the European Unionregulatory perspectives. ICH GCG ASEAN Training Workshop. 2011.

26. Ramachandra S. Lessons for the United States: biosimilar market development worldwide. Hospira Pharmaceuticals; 2013. https:// www.ftc.gov/system/files/documents/public_events/Follow-On\% 20Biologics\%20Workshop\%3A\%20Impact\%20of\%20Recent $\%$ 20Legislative $\% 20$ and $\% 20$ Regulatory $\% 20$ Naming $\% 20$ Proposals $\%$ 20on\%20Competition/ramachandra.pdf. Accessed 30 Aug 2017.

27. Scottish medicines consortium (SMC). Biosimilar Medicines Scotland: SMC; 2015. https://www.scottishmedicines.org.uk/ About_SMC/Policy_statements/Biosimilar_Medicines. Accessed 30 Aug 2017.

28. All Wales Medicines Strategy Group (AWMSG). Form B guidance note-appraisal submission. Vale of Glamorgan: All Wales Medicines Strategy Group (AWMSG); 2013. 